Article

\title{
Luminescence Sensitivity of Rhine Valley Loess: Indicators of Source Variability?
}

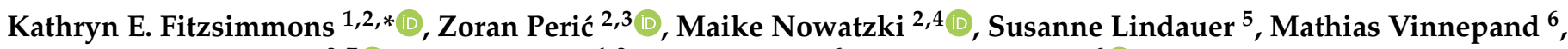 \\ Charlotte Prud'homme ${ }^{2,7}\left(\mathbb{D}\right.$, Aditi K. Dave ${ }^{1,2}$, Andreas Vött ${ }^{6}$ and Peter Fischer ${ }^{6}(\mathbb{C})$ \\ 1 Department of Geosciences, University of Tübingen, 72076 Tübingen, Germany; a.dave@mpic.de \\ 2 Research Group for Terrestrial Palaeoclimates, Max Planck Institute for Chemistry, 55128 Mainz, Germany; \\ zoran.peric@geol.lu.se (Z.P.); maike.nowatzki@ouce.ox.ac.uk (M.N.); charlotte.prudhomme@unil.ch (C.P.) \\ 3 Department of Geology, Lund University, SE-223 62 Lund, Sweden \\ 4 School of Geography and the Environment, University of Oxford, Oxford OX1 3QY, UK \\ 5 Curt-Engelhorn-Centre for Archaeometry, 68159 Mannheim, Germany; susanne.lindauer@ceza.de \\ 6 Institute of Geography, University of Mainz, 55128 Mainz, Germany; mavinnep@uni-mainz.de (M.V.); \\ a.voett@geo.uni-mainz.de (A.V.); p.fischer@geo.uni-mainz.de (P.F.) \\ 7 Institute of Earth Surface Dynamics, University of Lausanne, 1015 Lausanne, Switzerland \\ * Correspondence: kathryn.fitzsimmons@uni-tuebingen.de
}

\section{check for} updates

Citation: Fitzsimmons, K.E.; Perić, Z.; Nowatzki, M.; Lindauer, S.; Vinnepand, M.; Prud'homme, C.; Dave, A.K.; Vött, A.; Fischer, P. Luminescence Sensitivity of Rhine Valley Loess: Indicators of Source Variability? Quaternary 2022, 5, 1. https://doi.org/10.3390/quat5010001

Academic Editor: Dávid Molnár

Received: 29 July 2021

Accepted: 7 December 2021

Published: 21 December 2021

Publisher's Note: MDPI stays neutral with regard to jurisdictional claims in published maps and institutional affiliations.

Copyright: (c) 2021 by the authors. Licensee MDPI, Basel, Switzerland. This article is an open access article distributed under the terms and conditions of the Creative Commons Attribution (CC BY) license (https:// creativecommons.org/licenses/by/ $4.0 /)$.

\begin{abstract}
Loess provides a valuable terrestrial record of past environmental conditions, including the dynamics and trajectories of air mass circulation responsible for dust transport. Here we explore variations in the luminescence sensitivity characteristics of sedimentary quartz and feldspar as possible tools for identifying changes in source down a loess-palaeosol sequence (LPS). Luminescence sensitivity is a rapidly measurable index which is the product of interplay between source lithology and the history of the quartz or feldspar clasts. Variations in sensitivity of down profile may therefore reflect changes in sediment provenance as well as other factors such as weathering through pedogenesis. We undertake an empirical investigation of the luminescence sensitivity of quartz and feldspar from different grain-size fractions from the Schwalbenberg LPS in the German Rhine valley. We compare samples from a $30 \mathrm{~m}$ core spanning the last full glacial cycle with samples of oxygen isotope stage (OIS) 3-2 age exposed within nearby profile. We find an overall inverse relationship between quartz and feldspar sensitivity, as well as variability in sensitivity between different quartz grain sizes. Statistical analyses yield a significant correlation between $\mathrm{IR}_{50}$ sensitivity from unprocessed sediments and clay content, and feldspar sensitivity and Si/Al ratios down the core. Since $\mathrm{Si} / \mathrm{Al}$ ratios may indicate changes in provenance, the latter correlation suggests that $\mathrm{IR}_{50}$ measurements on unprocessed samples may be used to provide a reliable, rapid scan of source variability over millennial timescales.
\end{abstract}

Keywords: loess-palaeosol sequences; luminescence signal sensitivity; Schwalbenberg; sediment provenance; optically stimulated luminescence; infrared stimulated luminescence; Central Europe; Rhine valley

\section{Introduction}

Loess - a homogeneous, predominantly silt-sized aeolian sediment [1,2]—has long been recognised as a valuable terrestrial record of past environmental conditions [3-5]. Loess deposits drape some 10\% of the Earth's land surface, predominantly in the dry subhumid to semi-arid temperate mid-latitudes [6], accumulating almost continuously for more than one million years (1 My) in some regions [7-9]. It is assumed that classical stacked loess-palaeosol sequences (LPS) represent deposition and weathering in response to cooler glacial/stadial and warmer interglacial/interstadial climates, respectively $[4,5,10]$. Most aeolian dust is thought not to travel far, often deriving from fine-grained material transported by rivers from glaciated regions [11-13], although distal transport is also 
widely acknowledged, e.g., [14,15]. Loess deposits are implicitly linked with the pathways of major air masses thought to transport the dust, e.g., [16,17].

The provenance of loess sediment, and how provenance may have changed through time over the history of a deposit, is inferred from the trajectories and dynamics of atmospheric circulation systems, e.g., [18-20]. The most frequently used techniques for correlating aeolian dust deposits with likely source areas include bulk geochemistry [16,21-23], age distribution profiles of detrital zircons [24-26], and $\mathrm{Sr}-\mathrm{Nd}$ isotope ratios [15,27,28]. However, each of these approaches is limited in the information they may provide about loess provenance. Whilst in some instances bulk geochemistry can identify dust source changes due to variations in atmospheric circulation (such as a shift from mafic to felsic catchment source [29]), unequivocal links between source and sink can rarely be effectively identified because of homogenisation during transport $[23,27]$. Detrital zircons are limited in utility due to age overlap and variable zircon fertility within source rocks [25]. Radiogenic isotopes are limited to identifying the origins of clay minerals rather than the dominant silt-sized quartz and feldspar [27].

Since loess is dominated by quartz and feldspar grains, it is advantageous to explore their potential as indicators of source changes within LPS. Increasingly, researchers have been exploring variations in the luminescence characteristics of sedimentary quartz and feldspar as possible provenance tools [30-32]. Most investigations focus on quartz by virtue of its less complex crystalline framework. Approaches include cathodoluminescence signal spectra deriving from crystalline impurities, which relate to source rock formation $[33,34]$; electron spin resonance (ESR) signal intensity of luminescence centres, which are thought to reflect source rock age [34,35]; ratios of linearly-modulated optically stimulated luminescence (OSL) components as proxies for formation age [36,37]; and OSL sensitivity measurements as a qualitative indicator of source lithology and transport history [38-41]. Among these approaches, OSL sensitivity is the quickest to measure and has therefore been favoured in loess studies as a means to rapidly assess potential changes in sediment source down LPS profiles [42-44].

OSL sensitivity - the signal intensity per absorbed radiation dose-arises from the efficiency of charge traffic between traps and luminescence centres within a crystalline framework [45]. In a sedimentary context, sensitivity is the product of interplay between source lithology and the history of the mineral in question [32], including sedimentary history, extrusion/deposition and metamorphism. Consequently, shifts in sediment provenance may be observed through variations in OSL sensitivity down LPS [43]. Additional luminescence characteristics such as dose recovery [44] and infrared stimulated luminescence (IRSL)/OSL ratios [42] have also been observed to change in parallel, but require additional measurements. OSL sensitivity profiles have so far been generated for LPS sites on the Chinese Loess Plateau [43,44] and in Central Asia [42]. Despite the presence of thick loess deposits across Europe [3,46-48], however, this approach has yet to be tested on that continent.

Here we undertake an empirical investigation of the luminescence sensitivity characteristics of quartz and feldspar from different grain-size fractions at the Schwalbenberg LPS in the German Rhine valley. We test the potential of luminescence sensitivity as an indicator of changes in sediment source through time. Although feldspar, as a solid solution, exhibits substantially more complexity in its crystalline framework and recombination mechanisms than does quartz, e.g., [48-51], we undertake the first step towards exploring the potential of feldspar luminescence sensitivity for this purpose. We compare samples collected from a $30 \mathrm{~m}$ core spanning the last full glacial cycle at high resolution [52,53], with samples of oxygen isotope stage (OIS) 3-2 age exposed within a c. $6 \mathrm{~m}$ profile on the southern margins of the Schwalbenberg deposit [52]. The temporal overlap of the two localities during OIS 3 enables comparison of luminescence characteristics with respect to possible shifts in provenance during that timeframe. 


\section{Regional Setting}

This study focusses on the loess deposits of the Schwalbenberg site, located west of the city of Remagen and just north of the confluence between the rivers Ahr and Rhine, in western Germany (Figure 1). Loess deposits up to $30 \mathrm{~m}$ thick provide some of the thickest and most complete deposits in Western Europe [54-56]. The loess deposits at the Schwalbenberg site drape the fluvial terraces of the Rhine, and the Devonian sedimentary bedrock at higher altitudes [52,54] (Figure 1).

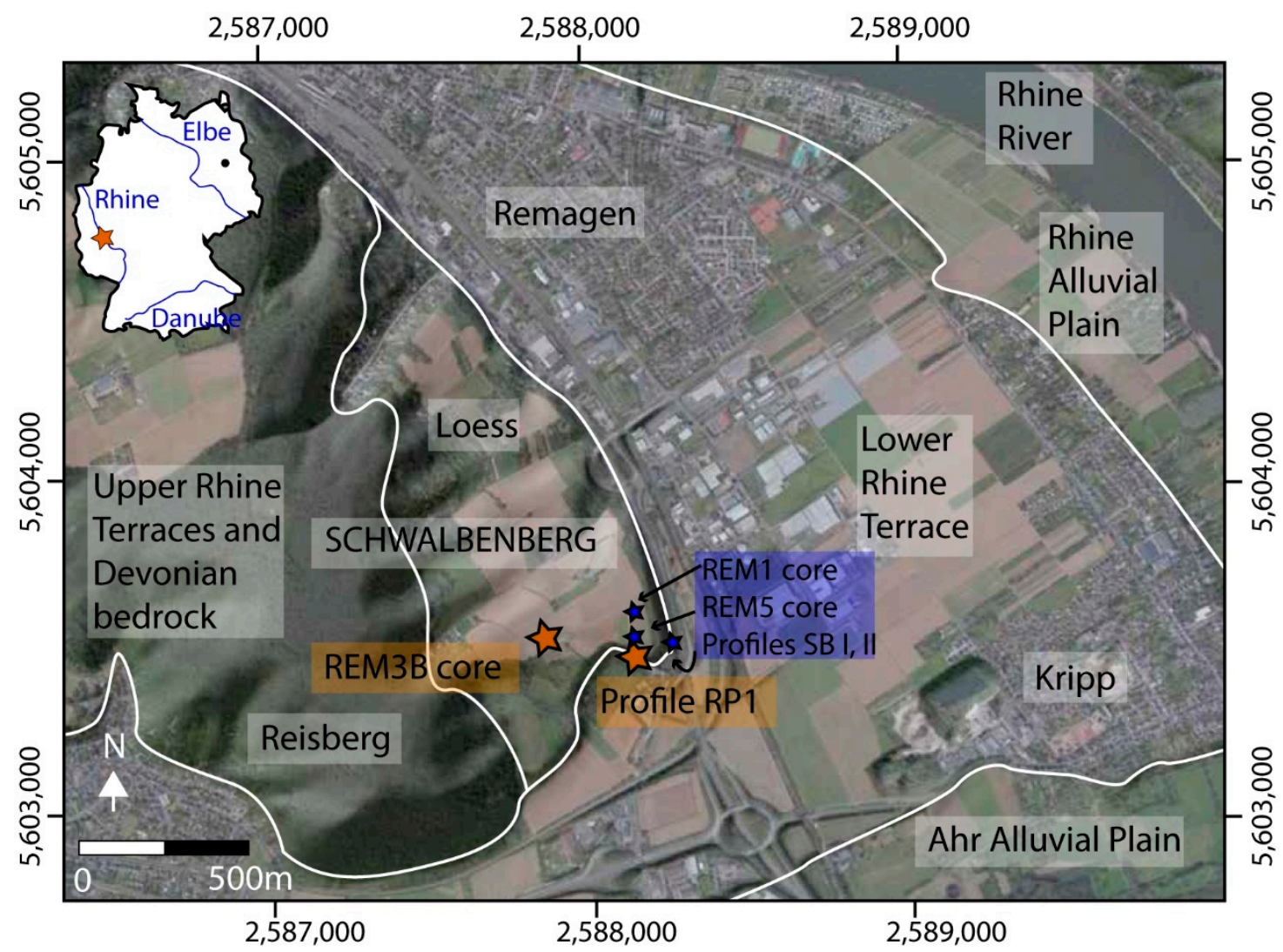

Figure 1. Map of the Schwalbenberg study area, west of the Rhine River and southwest of the city of Remagen (position within Germany shown in inset). The locations of the REM3B core and profile RP1 which form the focus of this study are indicated by orange stars. Blue stars denote previously studied sections and cores (SB I, SB II, REM1, REM5). Prominent breaks in slope are highlighted in white. The map is based on data from the digital elevation model (DGM 5), Geobasisdaten, Landesvermessungsamt Rheinland-Pfalz and Microsoft Bing Maps.

The loess deposits at Schwalbenberg have been the subject of a number of detailed stratigraphic, geochemical and sedimentological studies. Most of these investigated and excavated profiles were exposed along the margins of the hillslope, with the antiquity of the deposits inferred through correlation and observation of the c. $24 \mathrm{ka}$ age Eltville Tephra e.g., [57-60], and a luminescence chronology produced in [55]. More recently, four cores (REM 1, 3A/3B, 5) were drilled and sampled across the hillslope in order to reconstruct palaeoenvironmental change in four dimensions based on physical characteristics and geochemistry [53,54].

In this study, we focus on two sets of samples collected from the Schwalbenberg locality. Firstly, we sampled the upper $25 \mathrm{~m}$ of the $30 \mathrm{~m}$ long REM3B core. Fluvial sediments underlie the loess sequence below $25 \mathrm{~m}$ depth and are largely beyond the scope of interest here. The REM3B core was extracted adjacent the REM3A core described in [53]. It was collected in order to facilitate luminescence dating for chronological control and is considered to have effectively the same stratigraphy as the REM 3A core. Stratigraphic 
correlations suggest the REM3 cores to span the last full glacial cycle [53]. The basal metres comprise fluvial sandy silts, with some gravels, correlated based on elevation to the Rhine terraces of the last interglacial age and earlier [61]. Detailed correlation of a number of cores and profiles in the Schwalbenberg loess deposit established that the REM3 cores (A and B) span the last full glacial cycle [53]. The $27 \mathrm{~m}$ REM3 LPS is underlain by c. $3 \mathrm{~m}$ of fluvial sediments corresponding to pre-OIS 5 . The overlying c. $7.5 \mathrm{~m}$ contain predominantly clay-rich pedogenised loess interbedded with thin fluvial units, reworked and primary loess dating to the later stages of OIS 5 through to early OIS 3 [53]. A further c. $7 \mathrm{~m}$ of mostly loess, reworked loess and well developed calcaric cambisols overlies that part of the sequence and is interpreted to correspond to OIS 3. The predominantly primary loess of OIS 2 comprises the overlying $11.5 \mathrm{~m}$. The sequence is capped by $<1 \mathrm{~m}$ of modern soil corresponding to OIS 1.

In addition, we collected four samples from a c. $6 \mathrm{~m}$ thick loess profile, RP1, situated on the southern margins of the hill and approximately $200 \mathrm{~m}$ west of exposed profiles (SB I, II) described in previous studies [57,59,60,62-64]. Loess at RP1 accumulated over late OIS 3 into OIS 2 [53]. This chronology is based on radiocarbon dating of molluscs [65] and earthworm calcite granules [53], as well as luminescence dating using quartz OSL and polymineral post-infrared infrared stimulated luminescence (pIR-IRSL) on multiple grain-size fractions [53].

\section{Materials and Methods}

\subsection{Luminescence Measurements on the RP1 Profile}

Four luminescence samples were collected from profile RP1 and dated in [53]. Since the focus of this study lies with the sensitivity of the samples and not their age, we make reference to the ages solely for the purpose of comparing sensitivity in the regions of established temporal overlap. The samples were treated to isolate sand-sized (100-200 $\mu \mathrm{m})$ and very fine sand-sized $(63-100 \mu \mathrm{m})$ quartz for OSL dating, according to availability and using published methods [66]. These size fractions were loaded as 14-24 small aliquots (50-100 grains each) onto stainless steel discs for measurement (Table S1). Eighteen aliquots of fine-grained $(4-11 \mu \mathrm{m})$ polymineral material were additionally prepared from each sample according to [66]. The mass of sample on each disc could not be precisely measured; although we assume that the masses were consistent between the aliquots, we unfortunately cannot account for variation in our sensitivity calculations. This issue is also the case for the measurement of samples from the REM3B core.

All luminescence measurements were made on an automated Risø TL-DA-12 reader using blue-green or infrared light-emitting diodes (LEDs) to excite the OSL and IRSL/pIRIRSL signals, respectively [67]. Measurements were undertaken in the luminescence dating laboratory of the Curt Engelhorn Zentrum für Archaeometrie (CEZA) in Mannheim. Quartz OSL measurements for $\mathrm{D}_{\mathrm{e}}$ were undertaken using the single aliquot regenerative dose (SAR) protocol [68,69], using preheat and cutheat temperatures of $240{ }^{\circ} \mathrm{C}$ and $220{ }^{\circ} \mathrm{C}$, respectively, and applying four regenerative dose steps. The pIR-IRSL protocol [70] was applied to the polymineral fine-grained samples using an initial IRSL measurement temperature of $50{ }^{\circ} \mathrm{C}$ and pIR-IRSL measurement temperature of $290^{\circ} \mathrm{C}$ (and is henceforth designated as $\mathrm{pIR}_{50} \mathrm{IRSL}_{290}$ ). $\mathrm{D}_{\mathrm{e}}$ values calculated for the RP1 samples are listed in Table S2 and described in more detail in [53]. While not all aliquots exhibited characteristics acceptable for dating as discussed in [53], in this study we focus on the luminescence sensitivity of all aliquots measured irrespective of suitability for dating. Sensitivity was calculated from the luminescence signal arising from the test dose immediately following measurement of the natural signal. The signal counts were calculated from the integral of the first 0.5 of signal, from which an early background was subtracted, and are quantified in counts/Gy/s [38].

\subsection{Luminescence Measurements on the REM3B Core}

Core REM3B was split lengthwise for sampling under subdued red light conditions. One half of the core was sampled at semi-regular intervals for $\mathrm{D}_{\mathrm{e}}$ preparation and measure- 
ment, and the other half was sampled at the same depths for dose rate analysis to facilitate age calculations in the forthcoming work. The stratigraphy of the core was logged and correlated with the adjacent core REM3A to produce a composite core REM3 (described in $[53,54]$; Figure S1). A total of 102 samples were collected at high frequency (c. $10-50 \mathrm{~cm}$ intervals) down core REM3B. Each sample comprises ten vertical centimetres of sediment accumulation. The focus of this study is on the LPS sediments; nevertheless, five samples were measured from the basal fluvial units and are shown in our results but not considered in detail in our discussions. All REM3B core samples and their depths are listed in the Supplementary Information (Table S3).

We investigated luminescence signals and sensitivity using IRSL on 83 samples down the column; pIR ${ }_{50} \mathrm{IRSL}_{290}$ on 8 samples between c. 1.3-3.5 depth; pIR $200 \mathrm{IRSL}_{290}$ (using a higher initial IRSL temperature of $20{ }^{\circ} \mathrm{C}$ ) on 11 samples between 3.5-16.6 m depth; and OSL of two different size fractions for samples collected between 3.5-6.5 $\mathrm{m}$ and the lowermost $7 \mathrm{~m}$, respectively (Table S3). The pIR-IRSL measurements were all undertaken on 63-100 $\mu \mathrm{m}$ processed and density-separated material and therefore comprise K-feldspar rather than polymineral, as was the case for the fine-grained aliquots measured from the profile RP1. All luminescence measurements were made on automated Risø TL-DA20 readers using blue-green or infrared light-emitting diodes (LEDs) to excite the OSL and IRSL/pIR-IRSL signals, respectively [67]. Measurements were undertaken in the luminescence dating laboratory at the Max Planck Institute for Chemistry (MPIC), Mainz.

We first undertook a rapid assessment of IRSL signal increase with depth, and corresponding sensitivity, on 83 unprocessed samples down core REM3B. Three aliquots of unprocessed, unexposed sediment per sample were pipetted onto stainless steel discs for measurement of the natural IRSL 50 signal $\left(\mathrm{L}_{n}\right)$ at $50{ }^{\circ} \mathrm{C}$, followed by a test dose of approximately $37 \mathrm{~Gy}$, and measurement of the IRSL 50 signal following that test dose $\left(\mathrm{T}_{\mathrm{n}}\right)$. We selected a constant test dose that was the same as that applied to the RP1 samples to ensure consistency for the sample suite; the sensitivity results are henceforth referred to as $\mathrm{IR}_{50}$.

Following the initial $\mathrm{IR}_{50}$ scans, selected samples from regular intervals were treated to isolate very fine sand-sized $(63-90 \mu \mathrm{m})$ and very fine silt $(4-11 \mu \mathrm{m})$ material according to published methods for core samples [71]. Five very fine sand-sized (63-100 $\mu \mathrm{m})$ samples from the depth range c. 3.5-6.5 m were subsampled for extraction of both purified quartz and K-feldspar signal measurement, and 10 very fine silt-sized samples $(4-11 \mu \mathrm{m})$ from $>23 \mathrm{~m}$ depth were processed for quartz. The subsamples for quartz purification were etched in fluorosilicic acid according to published methods [72]. Following insights from earlier studies indicating that quartz signals in Remagen loess rarely yield reliable ages [54], we focused solely on processing and measurement of K-feldspar fractions for the remainder of the core. Six samples from the mid-lower part of the core $(7.6-16.6 \mathrm{~m})$ were processed solely for very fine sand-sized $(63-100 \mu \mathrm{m}) \mathrm{K}$-feldspar measurement.

We initially ran the $\mathrm{pIR}_{200} \mathrm{IRSL}_{290}$ protocol [70] on 6-12 aliquots (c. 200 grains) of K-feldspar below $3.5 \mathrm{~m}$ depth. Following observation of the signal arising from these samples, we observed variable sensitivity between samples and aliquots. We therefore compared measurements from the $\mathrm{pIR}_{200} \mathrm{IRSL}_{290}$ protocol with those using the lower initial temperature $\mathrm{pIR}_{50} \mathrm{IRSL}_{290}$ protocol on sample A0379 (3.5 $\mathrm{m}$ depth) and found that the latter yielded more consistent results. Thereafter we measured the K-feldspar core samples above $3.5 \mathrm{~m}$ depth using the $\mathrm{pIR}_{50} \mathrm{IRSL}_{290}$ protocol on 24 aliquots each, with four regenerative dose points. Three aliquots each from the five 63-90 $\mu \mathrm{m}$ quartz samples (c. 200 grains) were measured for OSL equivalent dose and sensitivity using the single aliquot regenerative dose (SAR) protocol $[68,69]$ using preheat and cutheat temperatures of $260{ }^{\circ} \mathrm{C}$ and $240{ }^{\circ} \mathrm{C}$, respectively, applying two regenerative dose steps and test doses of approximately $37 \mathrm{~Gy}$. Three aliquots of each very fine silt-sized sample from the lowest part of the core were measured using the SAR protocol, applying preheat and cutheat temperatures of $260{ }^{\circ} \mathrm{C}$ and $240{ }^{\circ} \mathrm{C}$, respectively, three regenerative dose steps and test doses of approximately 
37 Gy. Given the relatively small quantities of aliquots measured, mean equivalent doses are reported with $1 \sigma$ uncertainty.

Additional tests for luminescence characteristics were run on the 63-100 $\mu \mathrm{m}$ K-feldspar fractions. Dose recovery in response to a laboratory-applied beta radiation dose of c. $100 \mathrm{~Gy}$ was measured on three K-feldspar aliquots of sample A0375 (4.45 m), and residual dose tests following bleaching under sunlight and under an LED lamp were measured on six aliquots each of samples A0375 and A0376 (4.45 m and $4.25 \mathrm{~m}$ depth, respectively, bracketing the Eltville tephra; Table S4).

The luminescence sensitivities of the K-feldspar and quartz aliquots were calculated from the signal arising from the test dose immediately following measurement of the natural signal $\left(T_{n}\right)$, divided by test dose size. As for the samples run from profile RP1, signal counts were calculated from the integral of the first 0.5 of signal, from which an early background was subtracted. Feldspar signals were calculated from the elevated temperature measurements within the $\mathrm{pIR}_{290}$ protocols in order to ensure consistency between the different preheat temperatures. Sensitivity is quantified in counts/ Gy/s [38].

\subsection{Statistical Analyses to Test Correlations between Luminescence Sensitivity and Other Proxy Data}

Statistical analyses were performed on the bulk IRSL ${ }_{50}$ sensitivity dataset in order to test correlations between these data and stratigraphy, depth, OIS, clay percentage (as published in [53]) and $\mathrm{Si} / \mathrm{Al}$ ratios (as published in [73]). Details relating to these analyses are provided in the Supplementary Information. We did not analyse the sensitivity values derived from other luminescence protocols due to the small sample sizes of those datasets.

\section{Results}

Whilst the focus of this study is on the luminescence sensitivity of different minerals and grain-size fractions in the Schwalbenberg loess deposit, we also provide the approximate equivalent doses as a means of initially assessing the robustness of the age-depth relationships using the different protocols. We therefore present our results in three parts: an overview of the equivalent dose measurements, followed by test dose sensitivity data for the profile RP1 and the part of the core overlapping with RP1, and finally for the core REM3B.

\subsection{Equivalent Dose Measurements}

Most, but not all, aliquots of each respective measurement responded satisfactorily to the quartz OSL SAR or K-feldspar pIR-IRSL protocols. While signals from the $\mathrm{pIR}_{200} \mathrm{IRSL}_{290}$ and $\mathrm{pIR}_{50} \mathrm{IRSL}_{290}$ protocol measurements were both stable, sensitivity between aliquots and samples was more variable for the higher initial temperature protocol than for lower initial temperatures. Aliquots for equivalent dose calculation were accepted according to the criteria described in [53]. The $\mathrm{D}_{\mathrm{e}}$ values for each quartz and $\mathrm{K}$-feldspar sample were either averaged ( $\leq 6$ aliquots) or calculated using the Central Age Model (CAM) of [74] ( $>6$ aliquots; Tables S5 and S6). Given the possibility of residual dose contained within the pIR-IRSL signals [68], we quantified the residual dose on REM3B sample A0376 following bleaching for $300 \mathrm{~h}$ using an LED lamp. These measurements yielded a residual dose of $32.7 \pm 4.0$ Gy (Table S4). We assumed this value to be representative for loess at the site and therefore subtracted this value from all $\mathrm{D}_{\mathrm{e}} \mathrm{s}$ measured using the pIR-IRSL protocols.

We calculated approximate $D_{e}$ values for the unprocessed $I_{50}$ measurements by taking the mean of the three aliquot palaeodoses (Table S7).

Equivalent dose estimates are plotted vs. depth for both the profile RP1 and core REM3B in Figure 2. The pIR-IRSL samples in core REM3B are corrected for residual dose (for uncorrected age-depth, see Figure S3). 


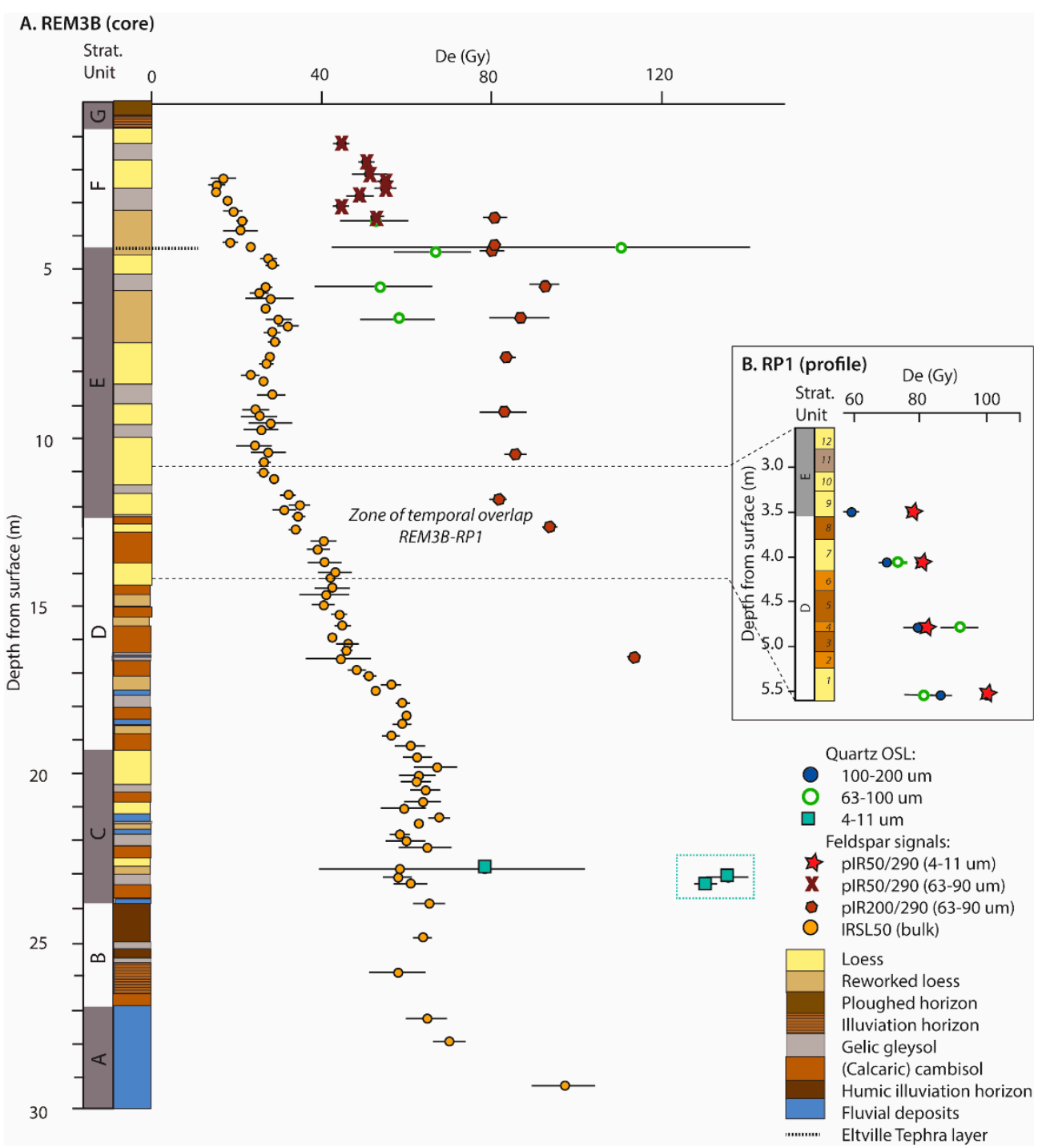

Figure 2. Plots illustrating sample equivalent dose (1 $\sigma$ error) with depth. (A) Equivalent dose vs. depth for the REM3B core, as measured on bulk samples ( $\mathrm{IR}_{50}$ signal; orange), fine-grained $(4-11 \mu \mathrm{m})$ and very fine sand-sized $(63-100 \mu \mathrm{m}) \mathrm{K}$-feldspar and quartz aliquots. The stratigraphy and stratigraphic units of the REM3 core as defined in [53] are shown for reference. Samples from the fluvial sediments at the base of the core are shown for completeness. (B) Equivalent dose vs. depth for the profile RP1 [53] based on 63-100 $\mu \mathrm{m}$ and 100-200 $\mu \mathrm{m}$ quartz and 4-11 $\mu \mathrm{m}$ polymineral measurements. The stratigraphy of the profile is also shown. The zone of temporal overlap between the REM3B core and RP1 profile, using the correlations published in [53], is constrained by dashed lines.

Equivalent dose values broadly increase with depth down the core REM3B, irrespective of measurement protocol (Figure 2A). This is to be expected given that this part of the Schwalbenberg deposit is interpreted to span the last full glacial cycle, from c. 130-0 ka [53]. The $\mathrm{IR}_{50}$ measurements on bulk, unprocessed samples also increase with depth and indicate that despite the impure signal measured on this material, it can be used to provide a rapid scan. Subvertical age-depth relationships can be observed in the stratigraphic units $\mathrm{E}$ (and transition to F), as well as $\mathrm{C}-\mathrm{D}$, suggesting very high sedimentation rates during the deposition of these units. These units have been correlated in [53] on the basis of combined lithostratigraphic features and physical characteristics with oxygen isotope stages (OIS) 4 and the early part of OIS 3 (units C-D), and with OIS 2 (units E-F). 
There are several notable discrepancies between the different measurement protocol results for the core REM3B. The lower preheat, residual-corrected K-feldspar pIR ${ }_{50} I_{290}$ protocols yield equivalent doses within error of, and consistent with, the quartz OSL results for the same size fraction $(63-90 \mu \mathrm{m})$. Where the quartz OSL measurements were paired with the K-feldspar pIR $_{50} \mathrm{IRSL}_{290}$, the K-feldspar $\mathrm{D}_{\mathrm{e}}$ values are at least $50 \%$ greater than those of the quartz, which is consistent with the higher internal dose rates in K-feldspar. This may be the product of higher residual doses than assumed, incomplete bleaching, or an inappropriate preheat temperature for the K-feldspar samples. However, we cannot preclude potential inaccuracies in the quartz as well, such as mixing, incomplete bleaching and multiple signal components, especially since we observe sedimentary reworking at, e.g., $4.5 \mathrm{~m}$ depth [53]. Unfortunately the lack of available measurable sample precluded a similar comparison for the 4-11 $\mu \mathrm{m}$ quartz OSL measurements in the lower part of the core at c. $23 \mathrm{~m}$ depth. However, two of the three samples yield $\mathrm{D}_{\mathrm{e}}$ values greater than the K-feldspar estimates further up the core (highlighted in the turquoise box in Figure 2), which is at least consistent with increasing age with depth.

The unprocessed $I_{50} D_{e}$ values from core REM3B also consistently increase with depth. We undertook no signal fading measurements on these aliquots and can therefore expect the $\mathrm{IR}_{50}$ values to underestimate those from the processed samples. Although the discrepancy between the unprocessed $\mathrm{IR}_{50}$ and other measured signals is significant and suggests substantial signal fading, our observations indicate that this quick scan approach can be useful to gain an overview of age-depth relationships down long sediment cores [75].

Equivalent dose values increase slightly with depth down profile RP1, irrespective of measurement protocol (Figure 2B). The profile chronology has been interpreted on the basis of combined luminescence and radiocarbon dating to span a relatively short time interval, c. 35-20 ka [53]. Consequently, it is to be expected that the $\mathrm{D}_{\mathrm{e}}$ values show limited variation. With one exception, the fine-grained polymineral samples yield larger $\mathrm{D}_{\mathrm{e}}$ values than in quartz, which is also to be expected given higher internal dose rates in feldspar. There is, however, a discrepancy between the $D_{e}$ values of the different quartz grain-size fractions. This may reflect the fact that the quartz signal is approaching saturation at these doses [76,77]. Furthermore, quartz from Schwalbenberg has previously been observed to contain a substantial contribution of medium component within the overall luminescence signal measured [54]. Whilst these discrepancies hold implications for dating profile RP1 (see discussion in [53]), they do not affect our comparison of test dose sensitivity here.

\subsection{Luminescence Sensitivity within Profile RP1 and in the Zone of Temporal Overlap between REM $3 B$ and RP1}

Profile RP1 has been previously dated using radiocarbon and luminescence, and is described in detail in [52]. It is interpreted to several millennia from late OIS 3 into the last glacial maximum of OIS 2 [53], and comprises primary loess in the lowermost excavated c. $20 \mathrm{~cm}$, overlain by c. $1 \mathrm{~m}$ of sediment bearing varying degrees of soil development with concomitant high clay proportions. A further c. $20 \mathrm{~cm}$ of primary loess overlies this OIS 3 soil complex. This is overlain by a thin, clay-rich palaeosol, over which $>0.5 \mathrm{~m}$ of primary loess caps the exposed sequence. A comparable stratigraphic progression is observed in the REM3 cores correlated in [52] to overlap temporally with the RP1 profile (Figure 3).

The luminescence sensitivity arising from the $\mathrm{IR}_{50}$ measurements on unprocessed material from core REM3B is illustrated in Figure 3A, along with the $\mathrm{pIR}_{200} \mathrm{IR}_{290}$ sensitivities on 63-90 $\mu \mathrm{m}$ K-feldspar aliquots of three overlapping samples. A $\log _{10}$ scale is used for the sensitivities, since the unprocessed $\mathrm{IR}_{50}$ material is substantially brighter than the processed sample measurements, which is to be expected given the larger numbers of grains on those aliquots. We observe significant variability in the $\mathrm{IR}_{50}$ measurements (compared with the small number of $\mathrm{pIR}_{290}$ samples). On the whole, $\mathrm{IR}_{50}$ sensitivities are higher within the primary loess units, and lower in the more clay-rich, pedogenic horizons. 


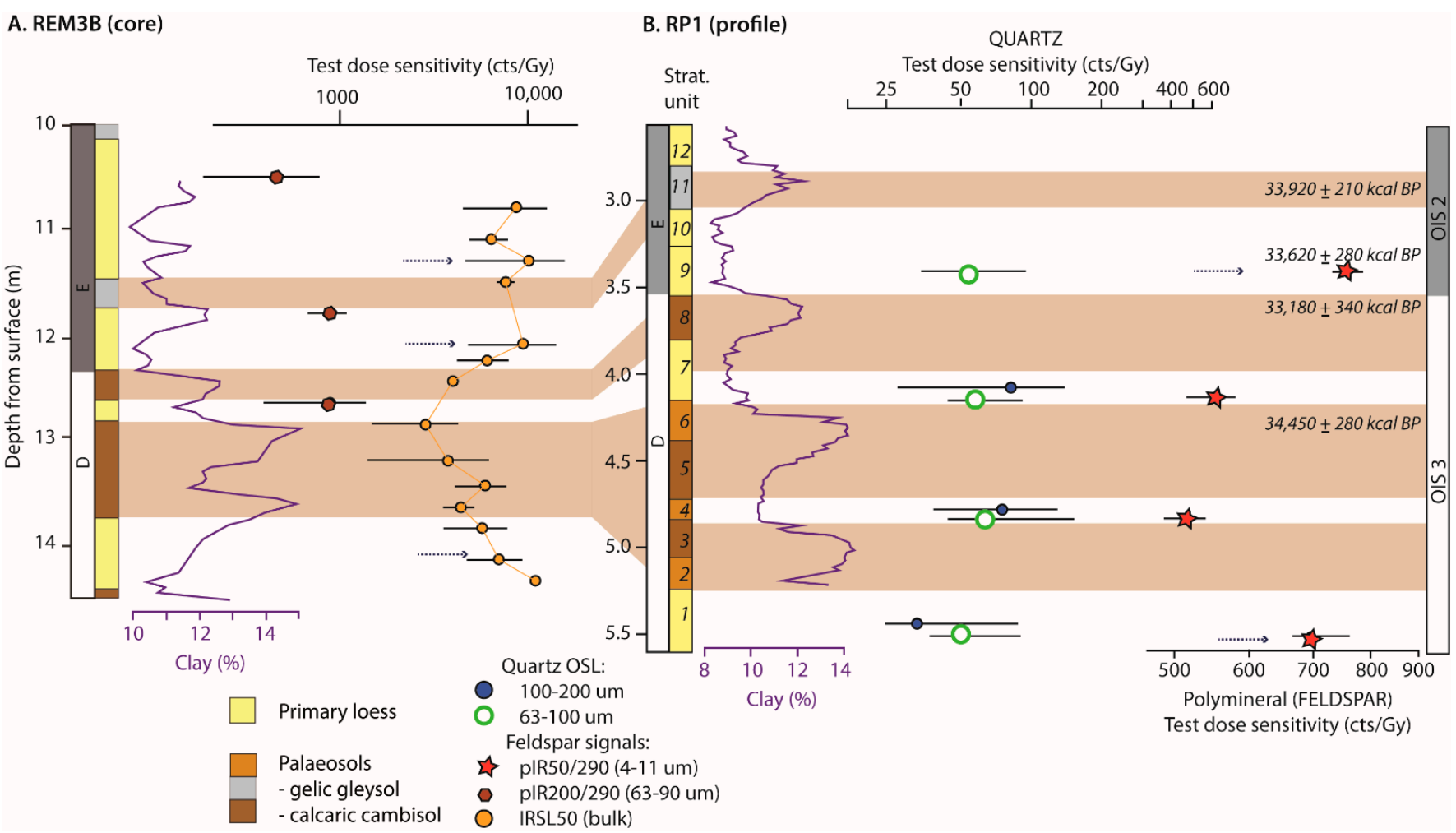

Figure 3. Comparison of luminescence test dose sensitivity (in cts/Gy) for the zone of temporal overlap between the REM3B core and RP1 profile. Stratigraphy and clay percentages, as well as the calibrated radiocarbon dates from earthworm calcite granules and accepted as final ages in [53], are shown for comparison with the sensitivity changes down sequence. Gelic gleysol and calcaric cambisol horizons are used for correlation across the figure. (A) Down core test dose sensitivity at REM3B measured for K-feldspar $\mathrm{pIR}_{290}$, and for bulk sediment using $\mathrm{IR}_{50}$. Error bars indicate standard deviations. (B) Down profile test dose sensitivity at RP1 based on two quartz size fractions as well as for K-feldspar $\mathrm{PIR}_{290}$. Since 14-24 aliquots were measured for each sample at RP1, sensitivity results are shown as box-plots with the median as a circle. Increased sensitivity in the feldspar measurements within loess horizons is highlighted by dark blue dashed arrows.

The luminescence sensitivity of the four samples collected from profile RP1, measured on 100-200 $\mu \mathrm{m}$ and 63-100 $\mu \mathrm{m}$ quartz and fine-grained polymineral fractions, is shown in Figure 3B. The data are presented as box-plots (medians shown by circles), with respect to stratigraphy and clay percentages. The Supplementary Information contains more detail on the respective fractions, including the absolute sensitivity values (Table S8), dot plots of all aliquots (Figure S4) and violin and box-plots for the individual fractions (Figures S5-S8). The sensitivities of both quartz size fractions vary minimally within the profile, although we concede that the sampling bias towards primary loess units may have influenced this result. The median values of the coarser (100-200 $\mu \mathrm{m})$ fraction are slightly higher than for the very fine sand-size $(63-90 \mu \mathrm{m})$ fraction, with the exception of the lowermost sample. By comparison, the substantially brighter fine-grained $(4-11 \mu \mathrm{m})$ polymineral (feldspar) fraction varies by c. $50 \%$ between the upper- and lowermost samples collected within the primary loess (which yield the greatest sensitivity values), and the middle samples from the OIS 3 palaeosol package.

Our sensitivity measurements on the unprocessed sample and on 63-90 $\mu \mathrm{m} \mathrm{K-feldspar}$ within core REM3B in the zone of temporal overlap with the RP1 profile facilitate a degree of comparison, albeit limited, with the sensitivity characteristics of the fine-grained polymineral samples in the latter. Despite deriving from different size fractions and therefore different numbers of grains contributing to the measured signals, the K-feldspar pIR $_{50} \mathrm{IRSL}_{290}$ sensitivity values in REM3B are similar to those observed at the equivalent 
stratigraphic unit in the RP1 profile. The $\mathrm{IR}_{50}$ sensitivity increases in the primary loess horizons and decreases by up to $50 \%$ in the more clay-rich palaeosol units. This trend appears to be echoed in the sensitivity values of the more coarsely sampled fine-grained polymineral measurements from the RP1 profile, although we stress that it is not possible to test this relationship more reliably without a larger number of samples.

\subsection{Luminescence Sensitivity down Core REM3B}

The luminescence sensitivity of all size and mineral fractions measured from REM3B is illustrated in Figure 4 with respect to stratigraphy and clay percentages (given as \% material $<2 \mu \mathrm{m}$ ). Given the smaller numbers of aliquots measured relative to the RP1 samples, we present these results as median values (circles) and standard deviations on a logarithmic scale. Absolute test dose sensitivity values for all measurements run from the REM3B samples are provided in Tables S7 and S9-S11.

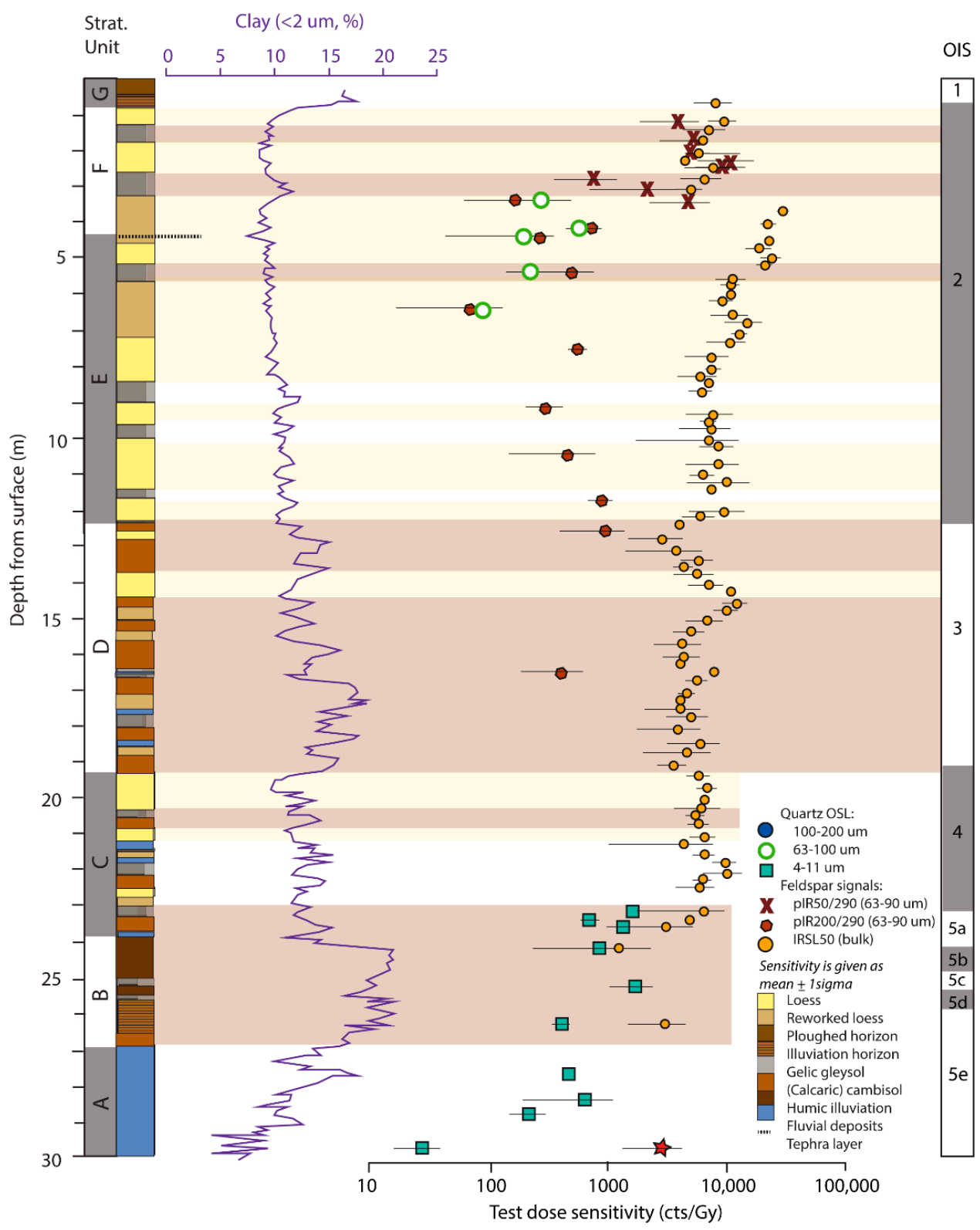

Figure 4. Comparison of luminescence sensitivity (median $\pm 1 \sigma$ ) with depth down the REM3B core, for quartz OSL, feldspar $\mathrm{pIR}_{290}$ and bulk $\mathrm{IR}_{50}$ signals, plotted against simplified stratigraphy, stratigraphic units and clay percentages from [53]. Major primary loess units are highlighted in yellow and palaeosol horizons in brown. 
The unprocessed $I_{50}$ results provide the most complete and highest resolution dataset from the REM3B core of the protocols used for measurement. As was already observed in the preceding section for the zone of temporal overlap with profile RP1, the IR ${ }_{50}$ sensitivities broadly increase within the primary loess units, and decrease within palaeosol horizons. The quartz samples are substantially less sensitive than the K-feldspar $\mathrm{pIR}_{290}$ and $\mathrm{IR}_{50}$ sensitivities; the basal fluvial fine-grained quartz is significantly less sensitive than finegrained quartz from the overlying LPS.

Statistical analyses (Supplementary Information) yield a significant difference between sensitivity values measured in palaeosol vs. loess stratigraphic units (Figure S9). Figure 5 highlights the observed trend between unprocessed $\mathrm{IR}_{50}$ sensitivity values measured from loess as compared to palaeosol units. Our statistical analyses established significant differences in $\mathrm{IR}_{50}$ sensitivity between OIS (Figure S10), as well as correlations between sensitivity and depth, clay percentage (Figure S11) and Si / Al (Figure S12), respectively (Table S12). We found that the main predictors of $\mathrm{IR}_{50}$ sensitivity were clay percentage (an indicator of weathering) and $\mathrm{Si} / \mathrm{Al}$ ratio (an indicator of source variability).

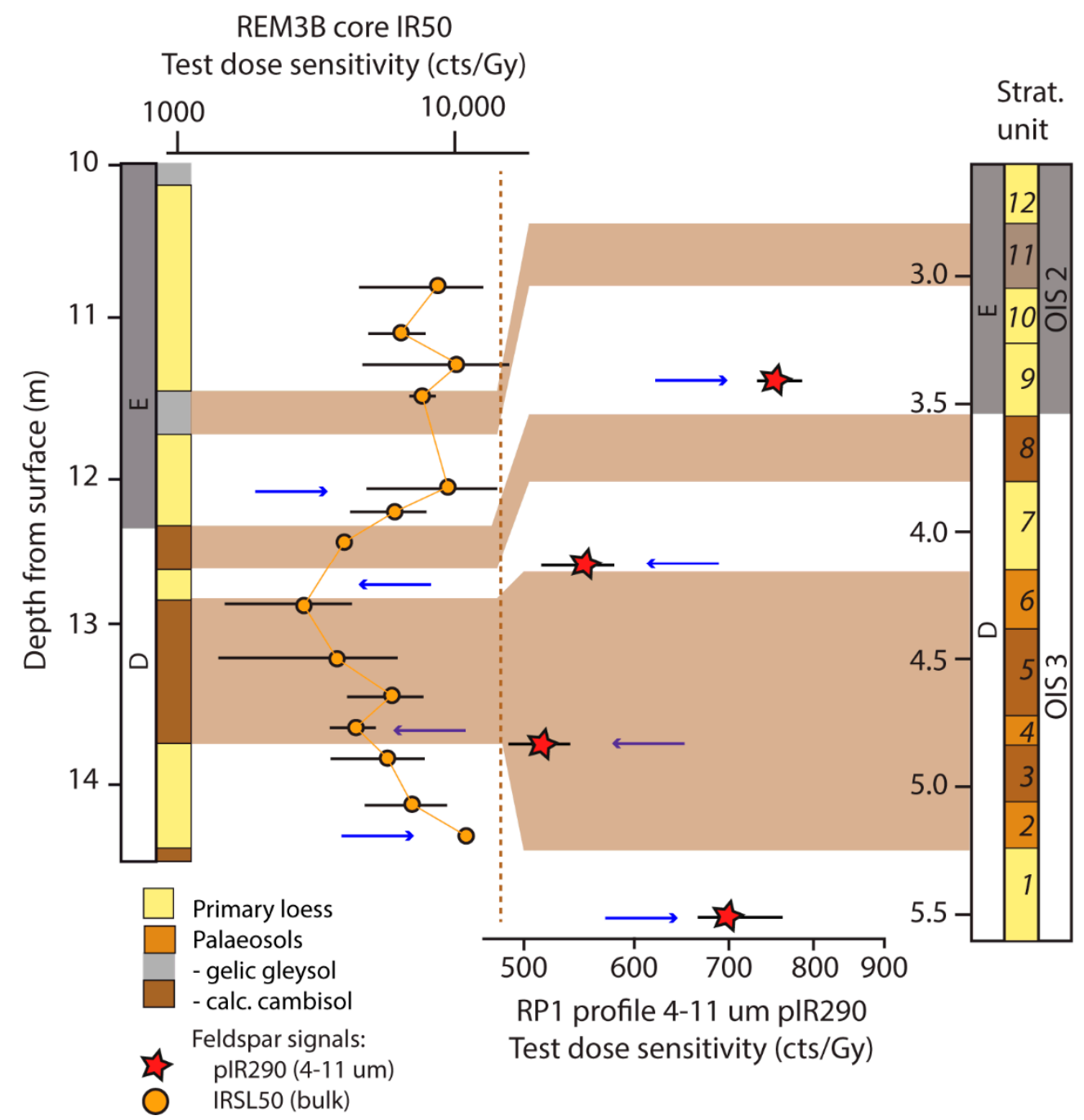

Figure 5. Comparison of bulk $\mathrm{IR}_{50}$ and polymineral 4-11 $\mu \mathrm{m}$ pIR $\mathrm{R}_{50} \mathrm{IR}_{290}$ luminescence sensitivity (orange and dark red, respectively) for the OIS 3-2 overlapping sections of RP1 and REM3B. Blue arrows highlight trends in the sensitivity data with respect to stratigraphic changes. 


\section{Discussion}

\subsection{Variability in Quartz and Feldspar Test Dose Sensitivity during OIS 3}

The profile RP1, and subsection of core REM3B which overlaps with it, correspond to OIS 3 and the transition to OIS 2 [53]. Millennial-scale oscillations in climate are known to have occurred across Europe and the wider North Atlantic region over this period [78-82]. At Schwalbenberg, the impact of short-term climatic oscillations, such as Greenland Interstadials, can be identified in the form of sedimentological and chemical changes within the stratigraphy both at RP1 and within the various cores, including REM3, collected from across the loess deposit [53]. The four samples measured from profile RP1 were collected from three clearly identifiable primary loess units (stratigraphic units 9-10, 7 and 1 in [53]; Figure 3) and one from a weakly developed palaeosol within a soil complex (stratigraphic unit 4). This provides us with the opportunity to identify whether OIS 3-2 climatic oscillations, which may include variability in dust transport pathways $[55,59,83]$ preserved in the form of source changes, are reflected in the luminescence sensitivities of our samples.

The quartz OSL sensitivities of the paired size fractions $(63-100 \mu \mathrm{m}$ and $100-200 \mu \mathrm{m})$ lie within error of one another without exception, and yield very little variability (Figure 3B). Standard deviations for the quartz sensitivities are very large irrespective of the number of aliquots measured (for aliquot quantities, see Table S2). As a result, we cannot reliably distinguish any differences in sensitivity of the quartz measured from RP1.

More substantial variability can be observed in the sensitivities derived from the feldspar (polymineral) signals; however, only the $I_{50}$ dataset yields sufficient sample size to investigate statistical significance. While the $4-11 \mu \mathrm{m}$ polymineral samples measured using $\mathrm{pIR}_{50} \mathrm{IR}_{290}$ from profile RP1 appear to yield higher sensitivities for the primary loess units 1 and 9, and lower sensitivities for the palaeosol unit 4 and palaeosol-loess transition 6/7 (Figure 3B), we recognise that additional samples are required to establish whether this trend is statistically meaningful. We also observe statistically significant higher sensitivities within primary loess units for the unprocessed $\mathrm{IR}_{50}$ signals from core REM3B, and lower sensitivities within pedogenic horizons (Figures 5A and S9). Only two processed K-feldspar samples from core REM3B actually overlap with the profile (the uppermost sample in Figure $3 \mathrm{~A}$ is equivalent to RP1 stratigraphic unit 12 and does not overlap). The sensitivities of these samples lie within error of one another and yield similar mean values, but the small sample number prevents more robust analysis. We therefore do not consider these further, although we note that these trends do not contradict the statistically significant trends in the $\mathrm{IR}_{50}$ data. Our observed trend is the inverse of that previously observed for quartz in other LPS across Eurasia [42,43].

\subsection{Variability in Rapidly Meaasured IR 50 Sensitivity down Core REM3B: Implications for Source Variability?}

Our study is the first empirical investigation of feldspar luminescence signal characteristics. In the preceding section we observed a degree of variation in feldspar signal between loess and palaeosol horizons within the OIS 3-2 period, although it is clear that the small number of samples measured using full $\mathrm{pIR}_{290}$ protocols hinders meaningful correlation. We henceforth focus on the variability of the higher resolution bulk $\mathrm{IR}_{50}$ signal dataset and its correlation with other variables which may provide predictors of $\mathrm{IR}_{50}$ sensitivity, with view to the hypothesis that $\mathrm{IR}_{50}$ sensitivity may provide a rapid scan for potential provenance changes.

Figure 6 illustrates the variability in $\mathrm{IR}_{50}$ sensitivity down the REM3B core with respect to stratigraphy, $\mathrm{Si} / \mathrm{Al}$ ratio as an indicator of provenance change $[59,83]$, potassium and clay percentages, $\mathrm{Ca} / \mathrm{Ti}$ ratios and total organic carbon (TOC), as published in [53]. There appears to be little systematic correlation between the $\mathrm{IR}_{50}$ sensitivity and the $\mathrm{Ca} / \mathrm{Ti}$ or TOC ratios (Figure 6). We visually defined an approximate threshold for $\mathrm{IR}_{50}$ sensitivity (5750 cts/Gy), above which values were considered "high". A visual comparison finds that in most, but not all, cases, $\mathrm{IR}_{50}$ sensitivity exceeds the threshold in samples collected 
from primary or reworked loess. We likewise find that in most, but not all, cases, $\mathrm{IR}_{50}$ sensitivity values from palaeosols or fluvial sediments fell below the defined threshold. Statistical analyses yield a similar transition value between palaeosol and (reworked) loess sensitivity. All sensitivity values below 3988 cts/Gy are measured for soil samples, and values above 10,016 cts/Gy are exclusively loess or reworked loess samples (excluding soil outliers). The overlap of palaeosol and loess values within the interquartile range includes sensitivity values from 5881 to 6154 cts/Gy, rendering the visual threshold of 5750 cts/Gy reasonable. Despite the overlap, the difference between soil and loess sensitivity values is statistically significant and may represent a switch in source-and therefore possibly transport pathway-between the two depositional unit types.

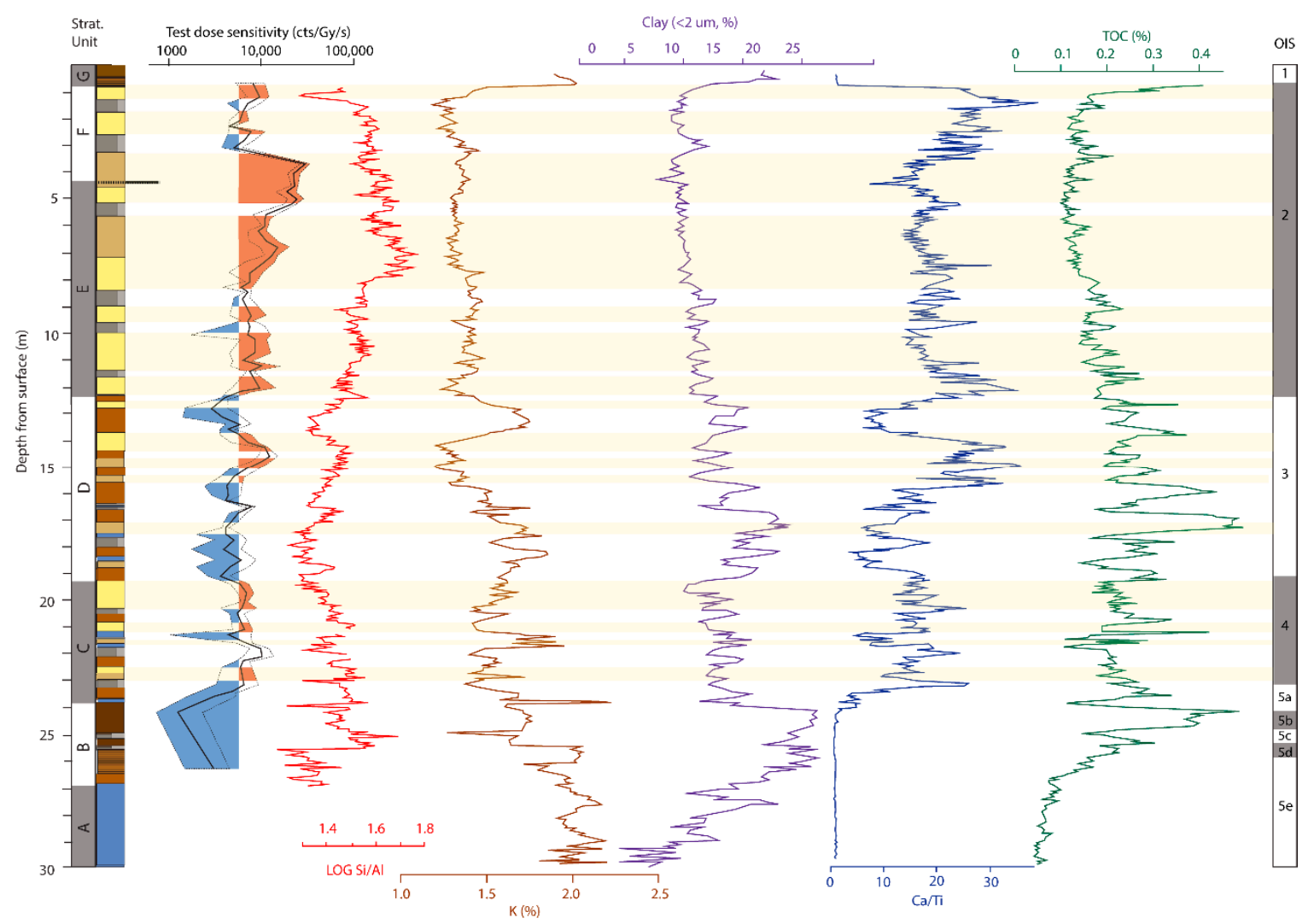

Figure 6. Comparison of bulk $\mathrm{IR}_{50}$ luminescence sensitivity (black solid line representing mean sensitivity, and dotted line representing $1 \sigma$ range) with $\mathrm{Si} / \mathrm{Al}$ ratio (red), potassium concentration (brown), percentage clay (defined as $<2 \mu \mathrm{m}$; purple), Ca/Ti ratio (dark blue) and total organic carbon (TOC; green), for the REM3 LPS. Primary and reworked loess unit depths are highlighted in yellow. Where $\mathrm{IR}_{50}$ sensitivities exceed $5750 \mathrm{cts} / \mathrm{Gy}$ and correspond to primary or reworked loess sediments, these are shaded in red-brown; reduced sensitivities below the same threshold which correlate to palaeosols or fluvial sediments are shaded in blue. Stratigraphy and correlation to oxygen isotope stages [53] are shown for comparison; stratigraphic legend can be found in Figure 4.

We also need to consider the possibility that pedogenesis influences $I_{50}$ sensitivity by altering feldspar charge transfer. That prospect is supported by a negative correlation between clay percentage and $\mathrm{IR}_{50}$ sensitivity $(\mathrm{r}=-0.69$; Table $\mathrm{S} 12)$, since the clay fraction increases with weathering intensity [53]. It is also important to consider the mode of pedogenesis within the sediments. Gelic gleysols are known to form in this region under partly stagnant conditions overlying the permafrost table and are distinct from calcic cambisols which also occur within the core. As such, different soil types may therefore alter feldspars in different ways. Whether this relationship is mechanistic or simply relates 
to a possible source switch to less sensitive feldspar-bearing sediments during pedogenic phases, which are higher in clay concentration, is unclear at this stage.

To test our hypothesis that $\mathrm{IR}_{50}$ sensitivity may reflect changes in sediment provenance through time, we compared down core $\mathrm{IR}_{50}$ sensitivity with variability in the $\mathrm{Si} / \mathrm{Al}$ ratio, which has been proposed as an indicator of source change, albeit one which can be affected by changes in grain size [59]. We find a striking visual similarity in the trend between $\mathrm{IR}_{50}$ sensitivity and the $\mathrm{Si} / \mathrm{Al}$ ratio (Figure 6), as well as a statistically significant positive correlation between the two parameters ( $r=0.67$; Table S12). Si/ Al was identified as one of the main predictors of sensitivity among all considered variables (Table S12). This positive correlation, together with reduced sensitivity observed within fluvial sediments which can be assumed to derive from different sources to the aeolian deposits, strengthens our proposal that changes in $\mathrm{IR}_{50}$ sensitivity may reflect variability in provenance.

We observe an inverse relationship between sensitivity and potassium concentration (Figure 6). Feldspar minerals represent a solid solution with varying proportions of $\mathrm{Ca}, \mathrm{Al}$ and $\mathrm{K}$ within their crystal framework and rarely occur as end-members; along with clay minerals, feldspars represent the main source of $\mathrm{K}$ within loessic sediment. It is therefore feasible that the proportion of $\mathrm{K}$ down the REM3B core reflects changes in the proportion of $\mathrm{K}$ within the feldspars that we are measuring for sensitivity. It has been suggested, in studies aiming to understand the phenomenon of anomalous fading within feldspars for dating, that $\mathrm{K}$ concentration may influence the density of available recombination centres [84-87], which might be used as an explanation for the variability that we observe here. However, the structural state of the feldspar is just as important in determining charge transfer [52], and thereby sensitivity. These states, and K concentration, may relate to sediment provenance, weathering through pedogenesis, or both.

\section{Conclusions}

Our statistical analyses demonstrate that the key predictors for $\mathrm{IR}_{50}$ sensitivity are clay percentage and $\mathrm{Si} / \mathrm{Al}$ ratios, which represent proxies for weathering/pedogenesis and source changes, respectively. We concede that our empirical study does not provide insights into the mechanisms which drive the changes in signal characteristics that we observe here, such as whether higher feldspar sensitivities represent sediments derived from older, metamorphosed or otherwise deformed source rocks. It may also be the case that the process of pedogenesis, which includes weathering of potassium-rich minerals and production of clays, may have played a role in influencing signal sensitivity. It is beyond the scope of this study to investigate the interplay between those characteristics within the Schwalbenberg LPS and how these may relate to combined alteration in feldspar crystalline structure and source changes. Notwithstanding these limitations, we suggest that our observations provide the first basis for future studies investigating the mechanisms driving feldspar sensitivity, and further exploring feldspar characteristics as possible indicators of provenance change down long sedimentary sequences. Furthermore, the rapidly measured bulk $I_{50}$ signal holds potential as a rapid and simple means to provide statistically robust datasets, once the mechanisms driving sensitivity are better understood.

Supplementary Materials: The following are available online at https:/ / www.mdpi.com/article/ 10.3390/quat5010001/s1, Figure S1: Photograph of core REM3A, collected adjacent REM3B [54], Figure S2: Equivalent dose vs. depth for the different mineral and grain-size fractions measured for profile RP1, Figure S3: Differences in uncorrected equivalent dose vs. depth for the different mineral and grain-size fractions down the REM3B core, Figure S4: Test dose sensitivity for the different mineral and grain-size samples measured for profile RP1, Figure S5: Test dose sensitivity for the five very fine sand $(63-90 \mu \mathrm{m})$ polymineral samples measured from RP1 in this study expressed as violin plot distributions, Figure S6: Test dose sensitivity for the five very fine sand $(63-90 \mu \mathrm{m})$ K-feldspar samples measured from RP1 in this study expressed as box-plots with (A) linear and (B) logarithmic scale on the x-axis, Figure S7: Box-plots of test dose sensitivity for the (A) 100-200 $\mu \mathrm{m}$ and (B) 63-100 $\mu \mathrm{m}$ quartz fraction of samples measured from profile RP1, Figure S8: Box-plots of test dose sensitivity for the $4-11 \mu \mathrm{m}$ polymineral fraction of samples measured from profile RP1, 
Table S1: Overview of luminescence samples collected from the profile RP1, Table S2: Summary of equivalent dose values for the different mineral and grain-size fractions measured for profile RP1 [53], Table S3: Overview of samples from core REM3B measured for this study with respect to measurement protocol, mineral and grain-size fraction, Table S4: Dose recovery and residual dose results for selected samples from core REM3B measured using the $\mathrm{pIR}_{200} \mathrm{IR}_{290}$ protocol, Table S5: Summary of depths and averaged De values and test dose sensitivity values for the ten finegrained $(4-11 \mu \mathrm{m})$ and five very fine sand $(63-90 \mu \mathrm{m})$ quartz OSL samples measured in this study, Table S6: Summary of depths, number of aliquots measured, measurement protocol and averaged uncorrected De values for the 18 very fine sand $(63-90 \mu \mathrm{m}) \mathrm{K}$-feldspar samples measured in this study using pIR-IR protocols, Table S7: Summary of depths, averaged De values and test dose sensitivity values for the bulk IRSL 50 measurements from the REM3B core, Table S8: Summary of depths, average and standard deviation of test dose sensitivity values for the different mineral and grain-size fractions measured for profile RP1, Table S9: Summary of depths, averaged De values and test dose sensitivity values for the ten fine-grained $(4-11 \mu \mathrm{m})$ quartz OSL samples measured in this study, Table S10: Summary of depths, averaged De values and test dose sensitivity values for the five very fine sand $(63-90 \mu \mathrm{m})$ quartz OSL samples measured in this study, Table S11: Summary of depths, averaged uncorrected De values and test dose sensitivity values for the 11 very fine sand $(63-90 \mu \mathrm{m})$ K-feldspar samples measured in this study using the pIR-IR protocols, Figure S9: $\mathrm{IR}_{50}$ sensitivity vs. stratigraphy, as divided between soils and loess, Figure S10: $\mathrm{IR}_{50}$ sensitivity vs. OIS [53], Figure S11: Log-transformed $\mathrm{IR}_{50}$ sensitivity plotted against clay content [53], Figure S12: Log-transformed $\mathrm{IR}_{50}$ sensitivity plotted against Si / Al ratios [88], Table S12: Settings and results of the statistical analyses testing the relationship of sensitivity with stratigraphy, OIS, depth, clay, and $\mathrm{Si} / \mathrm{Al}$ ratio.

Author Contributions: Conceptualization, K.E.F.; methodology, K.E.F. and M.N.; validation, K.E.F., Z.P. and M.N.; formal analysis, K.E.F., M.N. and S.L.; investigation, K.E.F., M.N., A.K.D., M.V. and C.P.; writing — original draft preparation, K.E.F.; writing — review and editing, all authors; funding acquisition, K.E.F., A.V. and P.F. All authors have read and agreed to the published version of the manuscript.

Funding: This research was funded by the German Research Council (DFG), grant numbers FI1941/51 and FI1918/4-1.Additional support to A.V. was provided by grant number VO938/25-1. Funding for M.N., Z.P., C.P. and A.K.D. was also provided by an independent Max Planck Research Group awarded to K.E.F., funded by the Max Planck Society.

Institutional Review Board Statement: Ethical review and approval was waived for this study since no human or animal subjects were involved.

Informed Consent Statement: Patient consent was waived since no human subjects were involved in the study.

Data Availability Statement: The data presented in this study are openly available in Mendeley Data at doi: 10.17632/sy7b653t23.1.

Acknowledgments: The authors would like to thank F. Sirocko (University of Mainz) for sharing laboratory facilities, as well as Tammy Rittenour (Utah State University) and three anonymous reviewers for their constructive comments on the manuscript.

Conflicts of Interest: The authors declare no conflict of interest.

\section{References}

1. Pécsi, M. Loess is not just the accumulation of dust. Quat. Int. 1990, 7-8, 1-21. [CrossRef]

2. Pye, K. The nature, origin and accumulation of loess. Quat. Sci. Rev. 1995, 14, 653-677. [CrossRef]

3. Fitzsimmons, K.E.; Markovic, S.; Hambach, U. Pleistocene environmental dynamics recorded in the loess of the middle and lower Danube basin. Quat. Sci. Rev. 2012, 41, 104-118. [CrossRef]

4. Liu, T.; Chang, T. The "Huangtu" (loess) of China. In Proceedings of the 6th INQUA Congress, Warsaw, Poland, 1961; 1964; Volume 4, pp. 503-534. Available online: https://www.researchgate.net/publication/285484646_The_\T1 \textquoterightHuangtu $\backslash T 1$ $\backslash$ textquoteright_loess_of_China (accessed on 11 November 2021).

5. Marković, S.B.; Stevens, T.; Kukla, G.J.; Hambach, U.; Fitzsimmons, K.E.; Gibbard, P.; Buggle, B.; Zech, M.; Guo, Z.; Hao, Q.; et al. Danube loess stratigraphy-Towards a pan-European loess stratigraphic model. Earth Sci. Rev. 2015, 148, 228-258. [CrossRef]

6. Fitzsimmons, K.E. Reconstructing palaeoenvironments on desert margins: New perspectives from Eurasian loess and Australian dry lake shorelines. Quat. Sci. Rev. 2017, 171, 1-19. [CrossRef] 
7. Buggle, B.; Hambach, U.; Kehl, M.; Markovic, S.B.; Zöller, L.; Glaser, B. The progressive evolution of a continental climate in southeast-central European lowlands during the Middle Pleistocene recorded in loess paleosol sequences. Geology 2013, 41, 771-774. [CrossRef]

8. Guo, Z.T.; Ruddiman, W.F.; Hao, Q.Z.; Wu, H.B.; Qiao, Y.S.; Zhu, R.X.; Peng, S.Z.; Wei, J.J.; Yuan, B.Y.; Liu, T.S. Onset of Asian desertification by $22 \mathrm{Myr}$ ago inferred from loess deposits in China. Nature 2002, 416, 159-163. [CrossRef]

9. Markovic, S.B.; Hambach, U.; Stevens, T.; Kukla, G.J.; Heller, F.; McCoy, W.D.; Oches, E.A.; Buggle, B.; Zöller, L. The last million years recorded at the Stari Slankamen (Northern Serbia) loess-palaeosol sequence: Revised chronostratigraphy and long-term environmental trends. Quat. Sci. Rev. 2011, 30, 1142-1154. [CrossRef]

10. Fink, J.; Kukla, G.J. Pleistocene climates in Central Europe: At least 17 interglacials after the Olduvai event. Quat. Res. 1977, 7, 363-371. [CrossRef]

11. Licht, A.; Pullen, A.; Kapp, P.; Abell, J.; Giesler, N. Eolian cannibalism: Reworked loess and fluvial sediment as the main sources of the Chinese Loess Plateau. GSA Bull. 2016, 128, 944-956. [CrossRef]

12. Smalley, I.; O'Hara-Dhand, K.; Wint, J.; Machalett, B.; Jary, Z.; Jefferson, I. Rivers and loess: The significance of long river transportation in the complex event-sequence approach to loess deposit formation. Quat. Int. 2009, 198, 7-18. [CrossRef]

13. Smalley, I.; Marković, S.B. Controls on the nature of loess particles and the formation of loess 567 deposits. Quat. Int. 2019, 502, 160-164. [CrossRef]

14. Újvári, G.; Stevens, T.; Svensson, A.; Klötzli, U.S.; Manning, C.; Németh, T.; Kovács, J.; Sweeney, M.R.; Gocke, M.; Wiesenberg, G.L.; et al. Two possible source regions for central Greenland last glacial dust. Geophys. Res. Lett. 2015, 42, 10399-10408. [CrossRef]

15. Zaarur, S.; Stein, M.; Adam, O.; Mingram, J.; Liu, J.; Wu, J.; Raveh-Rubin, S.; Erel, Y. Synoptic stability and anomalies in NE China inferred from dust provenance of Sihailongwan maar sediments during the past $\sim 80$ kyr. Quat. Sci. Rev. 2020, 239, 106279. [CrossRef]

16. Buggle, B.; Glaser, B.; Zöller, L.; Hambach, U.; Marković, S.; Glaser, I.; Gerasimenko, N. Geochemical characterization and origin of Southeastern and Eastern European loesses (Serbia, Romania, Ukraine). Quat. Sci. Rev. 2008, 27, 1058-1075. [CrossRef]

17. Obreht, I.; Hambach, U.; Veres, D.; Zeeden, C.; Bösken, J.; Stevens, T.; Marković, S.B.; Klasen, N.; Brill, D.; Burow, C.; et al. Shift of large-scale atmospheric systems over Europe during late MIS 3 and implications for Modern Human dispersal. Sci. Rep. 2017, 7, 5848. [CrossRef]

18. Fitzsimmons, K.E.; Nowatzki, M.; Dave, A.K.; Harder, H. Intersections between wind regimes, topography and sediment supply: Perspectives from aeolian landforms in Central Asia. Palaeogeog. Palaeoclim. Palaeoecol. 2020, 540, 109531. [CrossRef]

19. Li, Y.; Song, Y.; Kaskaoutis, D.G.; Chen, X.; Mamadjanov, Y.; Tan, L. Atmospheric dust dynamics in southern Central Asia: Implications for buildup of Tajikistan loess sediments. Atmos. Res. 2019, 229, 74-85. [CrossRef]

20. Stuut, J.-B.; Smalley, I.J.; O'Hara-Dhand, K. Aeolian dust in Europe: African sources and European deposits. Quat. Int. 2009, 198, 234-245. [CrossRef]

21. Gallet, S.; Jahn, B.M.; Lanoë, B.V.; Dia, A.; Rossello, E. Loess geochemistry and its implications for particle origin and composition of the upper continental crust. Earth Plan. Sci. Lett. 1998, 156, 157-172. [CrossRef]

22. Li, Y.; Song, Y.; Fitzsimmons, K.E.; Chen, X.; Wang, Q.; Sun, H.; Zhang, Z. New evidence for the provenance and formation of loess deposits in the Ili River Basin, Arid Central Asia. Aeol. Res. 2018, 35, 1-8. [CrossRef]

23. Újvári, G.; Varga, A.; Balogh-Brunstad, Z. Origin, weathering, and geochemical composition of loess in southwestern Hungary. Quat. Res. 2008, 69, 421-437. [CrossRef]

24. Bird, A.; Stevens, T.; Rittner, M.; Vermeesch, P.; Carter, A.; Andò, S.; Garzanti, E.; Lu, H.; Nie, J.; Zeng, L.; et al. Quaternary dust source variation across the Chinese Loess Plateau. Palaeogeog. Palaeoclim. Palaeoecol. 2015, 435, 254-264. [CrossRef]

25. Fenn, K.; Stevens, T.; Bird, A.; Limonta, M.; Rittner, M.; Vermeesch, P.; Andò, S.; Garzanti, E.; Lu, H.; Zhang, H.; et al. Insights into the provenance of the Chinese Loess Plateau from jointzircon U-Pb and garnet geochemical analysis of last glacial loess. Quat. Res. 2018, 89, 645-659. [CrossRef]

26. Stevens, T.; Carter, A.; Watson, T.P.; Vermeesch, P.; Andò, S.; Bird, A.F.; Lu, H.; Garzanti, E.; Cottam, M.A.; Sevastjanova, I. Genetic linkage between the Yellow River, the Mu Us desert and the Chinese Loess Plateau. Quat. Sci. Rev. 2013, 78, 355-368. [CrossRef]

27. Újvári, G.; Varga, A.; Ramos, F.C.; Kovács, J.; Németh, T.; Stevens, T. Evaluating the use of clay mineralogy, Sr-Nd isotopes and zircon $\mathrm{U}-\mathrm{Pb}$ ages in tracking dust provenance: An example from loess of the Carpathian Basin. Chem. Geol. 2012, 304, 83-96. [CrossRef]

28. Újvári, G.; Wegner, W.; Klötzli, U.; Horschinegg, M.; Hippler, D. Sr-Nd-Hf Isotopic Analysis of <10 mg Dust Samples: Implications for Ice Core Dust Source Fingerprinting. Geochem. Geophys. Geosyst. 2018, 19, 60-72. [CrossRef]

29. Obreht, I.; Zeeden, C.; Hambach, U.; Veres, D.; Marković, S.B.; Bösken, J.; Svirčev, Z.; Bačević, N.; 612 Gavrilov, M.B.; Lehmkuhl, F. Tracing the influence of Mediterranean climate on Southeastern Europe during the past 350,000 years. Sci. Rep. 2016, 6, 36334. [CrossRef]

30. do Nascimento, D.R.; Sawakuchi, A.O.; Guedes, C.C.; Giannini, P.C.; Grohmann, C.H.; Ferreira, M.P. Provenance of sands from the confluence of the Amazon and Madeira rivers based on detrital heavy minerals and luminescence of quartz and feldspar. Sed. Geol. 2015, 316, 1-12. [CrossRef]

31. Gray, H.J.; Jain, M.; Sawakuchi, A.O.; Mahan, S.A.; Tucker, G.E. Luminescence as a Sediment Tracer and Provenance Tool. Rev. Geophys. 2019, 57, 987-1017. [CrossRef] 
32. Sawakuchi, A.O.; Rodrigues, F.C.; Mineli, T.D.; Mendes, V.R.; Melo, D.B.; Chiessi, C.M.; Giannini, P.C. Optically Stimulated Luminescence Sensitivity of Quartz for Provenance Analysis. Methods Protoc. 2020, 3, 6. [CrossRef]

33. Nagashima, K.; Nishido, H.; Kayama, M.; Kurosaki, Y.; Ohgo, S.; Hasegawa, H. Composition of Asian dust from cathodoluminescence spectral analysis of single quartz grains. Geology 2017, 45, 879-882. [CrossRef]

34. Sun, Y.; Tada, R.; Chen, J.; Chen, H.; Toyoda, S.; Tani, A.; Isozaki, Y.; Nagashima, K.; Hasegawa, H.; Ji, J. Distinguishing the sources of Asian dust based on electron spin resonance signal intensity and crystallinity of quartz. Atmos. Environ. 2007, 41, 8537-8548. [CrossRef]

35. Toyoda, S.; Hattori, W. Formation and decay of the E1' center and of its precursor. Appl. Radiat. Isot. 2000, 52, 1351-1356. [CrossRef]

36. Gong, Z.; Sun, J.; Lü, T. Investigating the components of the optically stimulated luminescence signals of quartz grains from sand dunes in China. Quat. Geochron. 2015, 29, 48-57. [CrossRef]

37. Tsukamoto, S.; Nagashima, K.; Murray, A.S.; Tada, R. Variations in OSL components from quartz from Japan sea sediments and the possibility of reconstructing provenance. Quat. Int. 2011, 234, 182-189. [CrossRef]

38. Fitzsimmons, K.E. An assessment of the luminescence sensitivity of Australian quartz with respect to sediment history. Geochronometria 2011, 38, 199-208. [CrossRef]

39. Lü, T.; Sun, J. Luminescence sensitivities of quartz grains from eolian deposits in northern China and their implications for provenance. Quat. Res. 2011, 76, 181-189. [CrossRef]

40. Sawakuchi, A.O.; Blair, M.W.; Dewitt, R.; Faleiros, F.M.; Hyppolito, T.; Guedes, C.C. Thermal history versus sedimentary history: OSL sensitivity of quartz grains extracted from rocks and sediments. Quat. Geochron. 2011, 6, 261-272. [CrossRef]

41. Zheng, C.X.; Zhou, L.P.; Qin, J.T. Difference in luminescence sensitivity of coarse-grained quartz from deserts of northern China. Radiat. Meas. 2009, 44, 534-537. [CrossRef]

42. Li, Y.; Zhou, L. Variations of thermally and optically stimulated luminescence sensitivity of loess and pedocomplex samples from southern Tajikistan, Central Asia. Geochronometria 2020, 47. [CrossRef]

43. Lü, T.; Sun, J.; Li, S.H.; Gong, Z.; Xue, L. Vertical variations of luminescence sensitivity of quartz grains from loess/paleosol of Luochuan section in the central Chinese Loess Plateau since the last interglacial. Quat. Geochron. 2014, 22, 107-115. [CrossRef]

44. Stevens, T.; Adamiec, G.; Bird, A.F.; Lu, H. An abrupt shift in dust source on the Chinese Loess Plateau revealed through high sampling resolution OSL dating. Quat. Sci. Rev. 2013, 82, 121-132. [CrossRef]

45. Aitken, M.J. Thermoluminescence Dating; Academic Press: London, UK, 1985.

46. Haase, D.; Fink, J.; Haase, G.; Ruske, R.; Pécsi, M.; Richter, H.; Altermann, M.; Jäger, K.D. Loess in Europe-its spatial distribution based on a European Loess Map, scale 1:2,500,000. Quat. Sci. Rev. 2007, 26, 1301-1312. [CrossRef]

47. Rousseau, D.-D.; Boers, N.; Sima, A.; Svensson, A.; Bigler, M.; Lagroix, F.; Taylor, S.; Antoine, P. (MIS3 \& 2) millennial oscillations in Greenland dust and Eurasian aeolian records-A paleosol perspective. Quat. Sci. Rev. 2017, 169, 99-113.

48. Lehmkuhl, F.; Nett, J.J.; Pötter, S.; Schulte, P.; Sprafke, T.; Jary, Z.; Antoine, P.; Wacha, L.; Wolf, D.; Zerboni, A.; et al. Loess landscapes of Europe-Mapping, geomorphology, and zonal differentiation. Earth Sci. Rev. 2021, 215, 103496. [CrossRef]

49. Jain, M.; Ankjærgaard, C. Towards a non-fading signal in feldspar: Insight into charge transport and tunnelling from time-resolved optically stimulated luminescence. Radiat. Meas. 2011, 46, 292-309. [CrossRef]

50. Pagonis, V.; Jain, M.; Murray, A.S.; Ankjærgaard, C.; Chen, R. Modeling of the shape of infrared stimulated luminescence signals in feldspars. Radiat. Meas. 2012, 47, 870-876. [CrossRef]

51. Guralnik, B.; Li, B.; Jain, M.; Chen, R.; Paris, R.B.; Murray, A.S.; Li, S.H.; Pagonis, V.; Valla, P.G.; Herman, F. Radiation-induced growth and isothermal decay of infrared-stimulated luminescence from feldspar. Radiat. Meas. 2015, 81, 224-231. [CrossRef]

52. Riedesel, S.; Bell, A.M.; Duller, G.A.; Finch, A.A.; Jain, M.; King, G.E.; Pearce, N.J.; Roberts, H.M. Exploring sources of variation in thermoluminescence emissions and anomalous fading in alkali feldspars. Radiat. Meas. 2021, 141, 106541. [CrossRef]

53. Fischer, P.; Jöris, O.; Fitzsimmons, K.E.; Vinnepand, M.; Prud'Homme, C.; Schulte, P.; Hatté, C.; Hambach, U.; Lindauer, S.; Zeeden, C.; et al. Millennial-scale terrestrial ecosystem responses to Upper Pleistocene climatic changes: 4D-reconstruction of the Schwalbenberg Loess-Paleosol-Sequence (Middle Rhine valley, Germany). Catena 2021, 196, 104913. [CrossRef]

54. Vinnepand, M.; Fischer, P.; Fitzsimmons, K.E.; Thornton, B.; Fiedler, S.; Vött, A. Combining Inorganic and Organic Carbon Stable Isotope Signatures in the Schwalbenberg Loess-Palaeosol-Sequence Near Remagen (Middle Rhine Valley, Germany). Front. Earth Sci. 2020, 8, 276. [CrossRef]

55. Klasen, N.; Fischer, P.; Lehmkuhl, F.; Hilgers, A. Luminescence dating of loess deposits from the Remagen-Schwalbenberg site, western Germany. Geochronometria 2015, 42, 67-77. [CrossRef]

56. Schirmer, W.; Ikinger, A.; Nehring, F. Die terrestrischen Böden im Profil Schwalbenberg/Mittelrhein. (Terrestrial soils of the Schwalbenberg profile/Middle Rhine). Mainz. Geowiss. Mitt. 2012, 40, 53-78.

57. Schirmer, W. Late Pleistocene loess of the lower Rhine. Quat. Int. 2016, 411, 44-61. [CrossRef]

58. Bibus, E. Zur Relief-, Boden-und Sedimententwicklung am unteren Mittelrhein; Goethe-Universität Institut für Physische Geographie: Frankfurt am Main, Germany, 1980; Volume 1.

59. Profe, J.; Zolitschka, B.; Schirmer, W.; Frechen, M.; Ohlendorf, C. Geochemistry unravels MIS $3 / 2$ paleoenvironmental dynamics at the loess-paleosol sequence Schwalbenberg II, Germany. Palaeogeog. Palaeoclim. Palaeoecol. 2016, 459, 537-551. [CrossRef]

60. Schirmer, W. Würmzeitliche Böden am Mittelrhein. In Proceedings of the Program. und Exkursionsführer, 10. Tagung des AK Paläoböden der DBG, Bayreuth, Germany, 1991.

61. Schirmer, W. Eine Klimakurve des Oberpleistozäns aus dem rheinischen Löss. Eiszeit. Und Ggw. 2000, 50, 25-49. [CrossRef] 
62. Boenigk, W.; Frechen, M. The Pliocene and Quaternary fluvial archives of the Rhine system. Quat. Sci. Rev. 2006, 25, 550-574. [CrossRef]

63. Frechen, M.; Schirmer, W. Luminescence chronology of the Schwalbenberg II loess in the Middle Rhine valley. EG Quat. Sci. J. 2011, 60, 78-89. [CrossRef]

64. App, V. Die altsteinzeitliche Fundstelle auf dem Schwalbenberg bei Remagen. Ber. Zur Archäologie Mittelrh. Und Mosel 1995, 4, $11-136$.

65. Schiermeyer, J. Würmzeitliche Lößmollusken aus der Eifel; Universität Düsseldorf: Düsseldorf, Germany, 2002.

66. Lang, A.; Lindauer, S.; Kuhn, R.; Wagner, G.A. Procedures used for optically and infrared stimulated luminescence dating of sediments in Heidelberg. Ancient TL 1996, 14, 7-11.

67. Bøtter-Jensen, L. Luminescence techniques: Instrumentation and methods. Radiat. Meas. 1997, 27, 749-768. [CrossRef]

68. Murray, A.S.; Wintle, A.G. Luminescence dating of quartz using an improved single-aliquot regenerative-dose protocol. Radiat. Meas. 2000, 32, 57-73. [CrossRef]

69. Murray, A.S.; Wintle, A.G. The single aliquot regenerative dose protocol: Potential for improvements in reliability. Radiat. Meas. 2003, 37, 377-381. [CrossRef]

70. Buylaert, J.-P.; Jain, M.; Murray, A.S.; Thomsen, K.J.; Thiel, C.; Sohbati, R. A robust feldspar luminescence dating method for Middle and Late Pleistocene sediments. Boreas 2012, 41, 435-451. [CrossRef]

71. Perić, Z.; Adolphi, E.L.; Stevens, T.; Újvári, G.; Zeeden, C.; Buylaert, J.P.; Marković, S.B.; Hambach, U.; Fischer, P.; Schmidt, C.; et al. Quartz OSL dating of late quaternary Chinese and Serbian loess: A cross Eurasian comparison of dust mass accumulation rates. Quat. Int. 2019, 502, 30-44. [CrossRef]

72. Timar, A.; Vandenberghe, D.; Panaiotu, E.C.; Panaiotu, C.G.; Necula, C.; Cosma, C. Optical dating of Romanian loess using fine-grained quartz. Quat. Geochron. 2010, 5, 143-148. [CrossRef]

73. Vinnepand, M.; Fischer, P.; Zeeden, C.; Schulte, P.; Fiedler, S.; Jöris, O.; Hambach, U.; Fitzsimmons, K.E.; Prud’homme, C.; Peric, Z.; et al. Decoding geochemical signals of the Schwalbenberg Loess-Palaeosol-Sequences-A key to Upper Pleistocene terrestrial ecosystem responses in western Central Europe. In Proceedings of the EGU General Assembly Conference Abstracts, EGU21-10532, Online, 19-30 April 2021. [CrossRef]

74. Galbraith, R.F.; Roberts, R.G.; Laslett, G.M.; Yoshida, H.; Olley, J.M. Optical dating of single and multiple grains of quartz from Jinmium rock shelter, northern Australia. Part 1, Experimental design and statistical models. Archaeometry 1999, 41, 339-364. [CrossRef]

75. Preusser, F. Bulk sediment IRSL screening applied for high-resolution and fast age assessment of fluvial deposits in the Upper Rhine Plain. In Proceedings of the German Luminescence and Electron Spin Resonance Dating (DLED) Conference, Bingen, Germany, 8-10 November 2019.

76. Anechitei-Deacu, V.; Timar-Gabor, A.; Thomsen, K.J.; Buylaert, J.P.; Jain, M.; Bailey, M.; Murray, A.S. Single and multi-grain OSL investigations in the high dose range using coarse quartz. Radiat. Meas. 2018, 120, 124-130. [CrossRef]

77. Timar Gabor, A.; Vandenberghe, D.A.; Vasiliniuc, S.; Panaoitu, C.E.; Panaiotu, C.G.; Dimofte, D.; Cosma, C. Optical dating of Romanian loess: A comparison between silt-sized and sand-sized quartz. Quat. Int. 2011, 240, 62-70. [CrossRef]

78. Fuhrmann, F.; Diensberg, B.; Gong, X.; Lohmann, G.; Sirocko, F. Aridity synthesis for eight selected key regions of the global climate system during the last 60000 years. Clim. Past 2020, 16, 2221-2238. [CrossRef]

79. Fuhrmann, F.; Seelos, K.; Sirocko, F. Eolian sedimentation in Central European Auel dry maar from 60 to 13 ka. Quat. Res. 2021, 101, 4-12. [CrossRef]

80. Sirocko, F.; Knapp, H.; Dreher, F.; Förster, M.W.; Albert, J.; Brunck, H.; Veres, D.; Dietrich, S.; Zech, M.; Hambach, U.; et al. The ELSA-Vegetation-Stack: Reconstruction of Landscape Evolution Zones (LEZ) from laminated Eifel maar sediments of the last 60,000 years. Glob. Planet. Chang. 2016, 142, 108-135. [CrossRef]

81. Zeeden, C.; Hambach, U.; Veres, D.; Fitzsimmons, K.; Obreht, I.; Bösken, J.; Lehmkuhl, F. Millennial scale climate oscillations recorded in the Lower Danube loess over the last glacial period. Palaeogeog. Palaeoclim. Palaeoecol. 2018, 509, 164-181. [CrossRef]

82. Rasmussen, S.O.; Bigler, M.; Blockley, S.P.; Blunier, T.; Buchardt, S.L.; Clausen, H.B.; Cvijanovic, I.; Dahl-Jensen, D.; Johnsen, S.J.; Fischer, H.; et al. A stratigraphic framework for abrupt climatic changes during the Last Glacial period based on three synchronized Greenland ice-core records: Refining and extending the INTIMATE event stratigraphy. Quat. Sci. Rev. 2014, 106, 14-28. [CrossRef]

83. Schaffernicht, E.J.; Ludwig, P.; Shao, Y. Linkage between dust cycle and loess of the Last Glacial Maximum in Europe. Atmos. Chem. Phys. 2020, 20, 4969-4986. [CrossRef]

84. Huntley, D.J.; Lian, O.B. Some observations on tunnelling of trapped electrons in feldspars and their implications for optical dating. Quat. Sci. Rev. 2006, 25, 2503-2512. [CrossRef]

85. Valla, P.G.; Lowick, S.E.; Herman, F.; Champagnac, J.D.; Steer, P.; Guralnik, B. Exploring IRSL50 fading variability in bedrock feldspars and implications for OSL thermochronometry. Quat. Geochronol. 2016, 36, 55-66. [CrossRef]

86. Trauerstein, M.; Lowick, S.; Preusser, F.; Rufer, D.; Schlunegger, F. Exploring fading in single grain feldspar IRSL measurements. Quat. Geochron. 2012, 10, 327-333. [CrossRef]

87. Visocekas, R.; Zink, A. Tunneling afterglow and point defects in feldspars. Radiat. Eff. Defects Solids 1995, 134, 265-272. [CrossRef]

88. Vinnepand, M.; Fischer, P.; Zeeden, C.; Schulte, P.; Fiedler, S.; Jöris, O.; Hambach, U.; Fitzsimmons, K.E.; Prud'homme, C.; Peric, Z.; et al. Decoding multivariate geochemical signatures of the Upper Pleistocene Schwalbenberg loess-palaeosol sequenceImplications on changes of source areas and weathering intensities. Catena. in revision. 